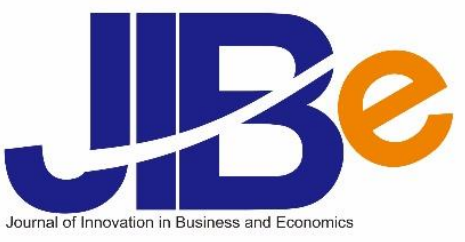

\section{Polychronicity: Model and analysis of conditional process toward employee turnover intentions}

Rian Andriani ${ }^{1}$, Disman Disman ${ }^{2}$, Eeng Ahman $^{3}$, Budi Santoso $^{4}$

\author{
Management Department, Universitas Adhirajasa Reswara \\ Sanjaya, Jl. Sekolah Internasional No 1-2, Bandung, Indonesia ${ }^{1}$ \\ Management Department, Universitas Pendidikan Indonesia, Jl, \\ Dr. Setiabudhi no. 229, Bandung, Indonesia $a^{2,3,4}$
}

DOI: https://doi.org/10.22219/jibe.v5i01.15867

\begin{abstract}
The hospitality industry in Indonesia is growing rapidly but lagging behind the readiness of human resources. The hotel industry has a crucial problem of retaining employees where there is a gap between the interests of employees and the interests of the company. Turnover intention is the main predictor of turnover, so aspects that can affect turnover intention will affect turnover. This study aims to describe and analyze the relationships between variables and dimensions in the research model or paradigm developed by the researcher. It tested the conditional process model using path analysis based on OLS regression and bootstrap methods. The population in this study were employees of the hotel industry in Indonesia, with a sample of 257 employees. The findings of this study are that the work environment has no direct effect on the variables of job satisfaction, employee engagement, and turnover intention but can interact as a moderator variable so that it effectively moderates the impact of polychronic on turnover intention through full mediation of job satisfaction and employee engagement.
\end{abstract}

Keywords: Polychronicity; job satisfaction; employee engagement; turnover intention; conditional process

\title{
Introduction
}

Employee turnover has been the greatest problem in the last decade (Boss, 2018). The turnover phenomenon can cause losses due to the large costs incurred by the company in re-recruiting new employees with similar competencies and even better replacing resigned ones (Grobelna et al., 2016). Turnover intention is the main predictor of turnover so that aspects that can affect turnover intention will affect turnover (Zagladi et al., 2015). Every year the turnover rate in the world has increased significantly and continued. A high turnover rate raises problems and hurts organizational performance (Shukla \& Sinha, 2013). Turnover costs the company in terms of costs, resources and motivation because the company loses its workforce. This loss, of course, must be replaced by finding new employees. The company at least incurs costs starting from the recruitment process to getting replacement employees. Employees who still survive will be motivated and enthusiastic about working, but it may happen that some employees will start looking for other jobs, resulting in turnover (Schaufeli et al., 2002). Companies need to be alert to turnover that exceeds the normal limit to ensure that turnover does not occur due to employee dissatisfaction, so the factors that cause it are critical to be fixed and must be addressed.

As the main predictor of turnover, the turnover intention is the desire or intention to quit work from a job based on one's own choice (Collins, 2010). Job satisfaction is influential when employees consider leaving the organization (Brimhall et al., 2014). In Indonesia, nearly three-quarters of respondents (72\%) stated that they would change jobs (find another job) within the next 1 year (Page, 2015). The factors that trigger employee turnover intention can be obtained from the direct, indirect, and total effects. To analyze the company's efforts to reduce employee turnover intention, it is necessary to analyze it using a conditional process. One of the factors for employee turnover intention is the work environment (communication, environment, coworker behavior) which results in employee dissatisfaction; work situations are the main reason for resignation among employees (Mano-Negrin \& Tzafrir, 2004). A study of 109 employees from

${ }^{1}$ E-mail: rian_andriani@ars.ac.id

2E-mail:disman@upi.edu

${ }^{3}$ E-mail: eengahman@upi.edu 
the textile industry in Pakistan revealed a work environment with negative and significant results on turnover intention (Qureshi et al., 2013).

One of the industries with the highest voluntary turnover rate in the world is the hospitality industry. The growth of hotels in Indonesia as one of the hospitality industries is so fast, even the largest number of hotel rooms in Indonesia is in Southeast Asia. The problem in the hospitality industry is finding the best experts, fast growth, but not in balance with HR readiness (Andriani et al., 2019). The importance of maintaining human resources and managing them can increase the company's competitiveness, which is an important success factor, especially in the hotel industry (Nadiri \& Tanova, 2010). The form of support from the Indonesian Government through the Ministry of Tourism is to implement a strategy to develop tourism in the industrial era 4.0, namely the development of human resources with the tagline Wonderful Human Resources 4.0. The quality of Human Resources (HR) must be able to support and satisfy the company, to continue to compete with other industries, the company must have a competitive advantage that is difficult to imitate, which is obtained from superior companies (productive, innovative, creative), always enthusiastic and committed with the support of a work environment which is conducive (Budiyanti et al., 2018; Noor \& Rokhimakhumullah, 2017). A company's success to survive in a very tight competition makes them more selective in finding HR. HR has a central role in the service sector (Ozkan et al., 2020).

Several studies in Indonesia related to employee turnover in the hotel industry, which ranged between 11-29\% per year (Arkhani, 2017; Monica \& Putra, 2017; Rahayu \& Riana, 2017; Riani \& Putra, 2017; Satwari et al., 2016; Widyantara, 2015; Widyasari et al., 2017; Yuda \& Ardana, 2017) so it can be categorized as very high. The phenomenon is that the hotel industry in Indonesia has a crucial problem: retaining employees where there is a gap between the interests of employees and those of the company. The company's inability to determine the causal factors that can lead to turnover intention is, of course, the beginning of the inability of the hotel industry to provide relevant solutions and programs and make company employees more loyal. Polychronicity behavior can significantly reduce the turnover intention of employees working in the hotel industry (Zhang, 2015), where employees must adapt to high working conditions and be ready to provide excellent service to hotel guests (Andriani \& Disman, 2020). The conditional process model related to the turnover intention of hotel industry employees by combining mediating variables (job satisfaction and employee engagement) and moderation of the work environment can be a solution to reduce employee turnover intention.

Based on our introduction, the research questions in this study are: 1) how to analyze the categorical moderation model on the effect of polychronicity and work environment on job satisfaction of hotel industry employees; 2) how to analyze the conditional process model on the effect of polychronicity, job satisfaction, and work environment on employee engagement in the hotel industry?; 3) how is the conditional process model analysis on the effect of polychronicity, job satisfaction, employee engagement, and work environment on turnover intention of hotel industry employees?

\section{Literature Review}

\section{Polychronicity}

Edward Hall (1959) was the first researcher to classify culture as monochronic or polychronic. Hall, in a published interview with Allen Bluedorn, expanded the meaning of polychronicity in two ways. First, he changed the definition of polychronic by adding an attitude element, Hall arguing that "a polychronic culture is a culture in which people value, and hence practice, engage in several activities and events at the same time" (Bluedorn, 1998; Bluedorn \& Jaussi, 2007; Poposki \& Oswald, 2009). This definition includes elements of behavior. (i.e., multitasking behavior) and the evaluation element and the causal relationship between the two: Polychronic people do several activities simultaneously and value doing this, and the assumed reason for doing so is judgment (König \& Waller, 2010). Second, Hall included several other phenomena under the polychronic concept; for example, he argued that polychronic people are more related to orientation relationships, have more complex information networks, pay less attention to formal time constraints, and be more easily distracted than monochronic people. He also describes high polychronic culture as "high context" (Bluedorn, 1998; D. K. Palmer \& Schoorman, 1999), meaning that much needs to be known about the context in any communication. Understand what is being revealed. Furthermore, Hall assumes polychronic culture to be time intangible, meaning that people in that culture do not believe that "time is money" or manageable time; on the contrary, they see it "only as a backdrop to undisclosed events" (D. Palmer, 2006; D. K. Palmer \& Schoorman, 1999).

Polychronicity is an individual's preference for shifting attention between ongoing tasks, rather than focusing on one task until completion and then moving on to another (Kantrowitz et al., 2012; Poposki et al., 2009). In its strictest sense, polychronic culture is one in which people value, and therefore practice, engaging in several activities and tasks simultaneously. People who prefer to focus on one task until 
completion and then move to the next are considered monochronic. In contrast, people who prefer to work on several tasks simultaneously are considered polychronic. Compared with monochronic individuals, polychronic individuals emphasize relationships rather than duties and privacy and build long-term relationships with family, friends, and business partners (Bluedorn et al., 1992; Kayaalp, 2014). Polychronic organizes activities concurrently, intends to move back and forth to complete tasks, and tends to view scheduled events as part of normal activities rather than deviations or interruptions (Bluedorn \& Jaussi, 2007; Hecht \& Allen, 2005).

There is little or no effect in polychronic individuals when things keep changing, nothing seems solid or decisive, especially plans for the future, and there are always changes in the most important plans until the last minute (Grobelna, 2019; Plocher et al., 2002). As a fundamental and profound cultural dimension, polychronic is a dimension of human time that involves the extent to which activities are organized by scheduling two or more events at one time (Norris, 2015; Onken, 1999). More precisely, polychronic is the extent to which people in a culture (Bluedorn et al., 1999) prefer to be engaged in two or more jobs at the same time; believes that preference is a good way of doing work. Not all employees react positively in completing several tasks at once, but as polychronic individuals such as multi-tasking, they will find more complex tasks, and the completion is more satisfying than monochronic (Goonetilleke \& Luximon, 2010; Reynolds, 2008). Polychronic people are said to understand and predict when their participation is required even if it is performing several tasks simultaneously, thus encouraging them to move back and forth between multiple tasks and projects (Jang \& George, 2012). Polychronicity has three dimensions usually associated with: time use preference, context, and time tangibility (D. K. Palmer \& Schoorman, 1999).

Positive job traits such as polychronic (multi-tasking behavior) can increase job satisfaction and reduce employee intention to resign (Arndt et al., 2006). Research on 609 hotel employees in the United States revealed that polychronic has a negative and significant effect on turnover intention; their findings suggest that polychronic (i.e., multitasking) has increased job satisfaction, reducing turnover (Jang \& George, 2012). A study of 251 restaurant companies in the United States found that polychronic has a negative and significant effect on turnover intention (Zhang, 2015).

\section{Job Satisfaction}

Employees are an important asset of the organization, so it is essential to satisfy them (Andriani, 2014; Farooqui \& Nagendra, 2014). Some researchers have defined satisfaction as a positive feeling or aggressive response; others define it as the gap between expected and actual earnings (Afzalur Rahim et al., 2015; Gözükara \& Çolakoğlu, 2016; Tsai et al., 2007). Job satisfaction is defined as an emotional atmosphere that evokes happiness from an employee regarding the work situation, supervisors, work assignments, and the organization (Yeh, 2014). Job satisfaction is an attitude in the aspect of work, which is not visible but is related to beliefs with certain behaviors (Chan et al., 2016). Job satisfaction can be interpreted as positive and negative feelings held by employees depending on work, colleagues, and the work environment (Uhl-Bien et al., 2014). Establishing a sense of job satisfaction is a good task for managers. A work environment that is conducive, challenging, and helps the achievement of high abilities and employees who find job satisfaction are the most important targets in human resource management.

The measure of job satisfaction is divided into two, namely intrinsic and extrinsic. Intrinsic satisfaction is determined by achievement, independence, and diversity, while extrinsic satisfaction includes salary, promotion, relationship with coworkers, and working conditions (Grobelna et al., 2016; Mount \& Bartlett, 2002). There are several indicators of job dissatisfaction which include absenteeism, complaints, demotivation, high turnover, tardiness, and so on, while factors that determine the level of employee job satisfaction, for example, financial benefits and benefits, career growth and promotion, work environment, supervisors and coworkers (Kabak et al., 2014). Job satisfaction occurs because of higher performance so that active employees get satisfaction (Ivancevich et al., 2014).

Dissatisfied employees will leave the organization, look for new positions and even resign (Robbins \& Judge, 2018). Research on 781 employees in the health industry in South America found that job satisfaction has a negative and significant effect on turnover intention, concluding that positive work can increase employee retention (Valentine et al., 2011). Research on 200 employees who work at universities in Turkey shows that job satisfaction has a negative and significant effect on turnover intention. Job satisfaction is an important predictor for employees who want to keep or leave the company. When they are not satisfied, they will leave the organization (Alniaçik et al., 2013). A study of 46 leaders and 158 employees in the Norwegian city government revealed that low job satisfaction could lead to turnover intention (Amundsen \& Martinsen, 2014). A study of 6207 truck drivers in the United States revealed job satisfaction with a negative and significant effect on turnover intention (Huang et al., 2015). Studies on 251 
employees of restaurant companies in the United States provide negative and significant job satisfaction results on turnover intention (Zhang, 2015). A study of 194 nurses and 181 patients in Southern Italy gave negative and significant results on turnover intention (De Simone et al., 2018).

Employee Engagement

Engagement was originally conceptualized by Kahn in 1990 and later operationalized by Maslach and Leiter in 1997 (Beardwell \& Thompson, 2017). Job engagement refers to a positive state of mind, increased satisfaction, a job supported by strength, dedication, and absorption. People engage in enthusiastic, inspired, proud, and challenged behavior at work, and are willing to try while maintaining concentration and enjoy doing tasks and are persistent in the face of difficulties and distractions, such as time at work is fast, and possibly difficult for him to give up his job (Dilig-Ruiz et al., 2018; Schaufeli et al., 2002). The concept of engagement also explains the extent of commitment, dedication and loyalty to the organization, work, colleagues and superiors. Engagement as a positive attitude towards the company (Schiemann, 2014). The three dimensions of engagement (Lu et al., 2016; Schaufeli et al., 2002) are vigor, dedication and absorption.

Employees who are engaged have an attachment to remain loyal to their company, while employees who are not bound (disengaged) intend to leave the company, disengaged employees are ready to withdraw their energy and lead to resign (Shuck \& Reio, 2014). A study of 111 employees in Turkey shows that engagement has a negative and significant effect on turnover intention (Elçi et al., 2014). Research on 208 female nurses in Iran revealed that engagement has a negative and significant effect on turnover intention (Shahpouri et al., 2016). A study of 194 nurses and 181 patients in Southern Italy found that engagement has a negative and significant effect on turnover intention (De Cuyper et al., 2011).

\section{Work Environment}

Employees who are comfortable in their work environment will work efficiently and enjoy the work process; companies must improve work environment factors and ensure the peace of their employees (Boev et al., 2015; Khuong \& Vu, 2014). The work environment is an indicator for measuring employee satisfaction (Coomber \& Louise Barriball, 2007). Companies need to build a work environment so that employees feel support in career development, create new concepts for the work environment to increase employee effectiveness while providing an ergonomically designed workspace that can improve employee welfare, and support employee work tasks by adapting to changes in work processes through space work that is flexible, mobile, and adaptable, well-structured work environments also enhance relationships and collaboration between employees and departments (AbuAlRub et al., 2016; Turkyilmaz et al., 2011). Employees should be comfortable in a work environment where providing facilities, safety, health. The support of the work environment has succeeded in creating a positive meaning in the achievements shown by employees. An effective work environment makes employees committed and increases motivation to be satisfied and more efficient and productive (Danish et al., 2013).

\section{Turnover Intention}

Employees as human capital are the main control holders in every operational activity of an organization, so maintaining their employees is certainly a difficult matter for every company. Companies must be able to control employee turnover intention because turnover behavior affects company dynamics. Employee turnover is the rate at which people leave an organization (Armstrong \& Taylor, 2014; DiligRuiz et al., 2018). Turnover occurs when an employee leaves the company (Moorhead \& Griffin, 2013). Turnover can harm a company in terms of funds, resources, and motivation. If employee turnover occurs, the company loses several workers; this loss must be replaced with new employees, so the company must pay costs ranging from recruitment to ready-to-use labor. Substitution must be avoided, especially if it is at an unusual level; the factors causing it needs to be identified and addressed as far as possible.

Especially for companies with a high enough rate of employee resignation, they must be cautious, because this kind of change is a warning, especially if the resignation of employees comes from potential employees and the recruitment of new employees can be a serious problem in the future (Aksu, 2008; Dwiyanti et al., 2019). Employee resignation can be seen as the final step for a dissatisfied employee, and this separation of employees will negatively affect organizational productivity. New employees must identify themselves with other employees and adhere to their new organization's rules and values. If they can manage to accept the new organization as a part of themselves, this will bring the possibility of success in their future careers (Dick et al., 2004).

Based on previous research, it can be concluded that polychronic behavior that is carried out effectively can increase employee job satisfaction and employee engagement and reduce employee turnover intention, which is moderated by the work environment. In this study, the author uses a conditional process 
analysis, which is a combination of mediating variables (job satisfaction and employee engagement) and moderation (work environment) to intervene and provide interactions between research variables so that it can be a company effort, especially in the hotel industry, to reduce the turnover intention rate high.

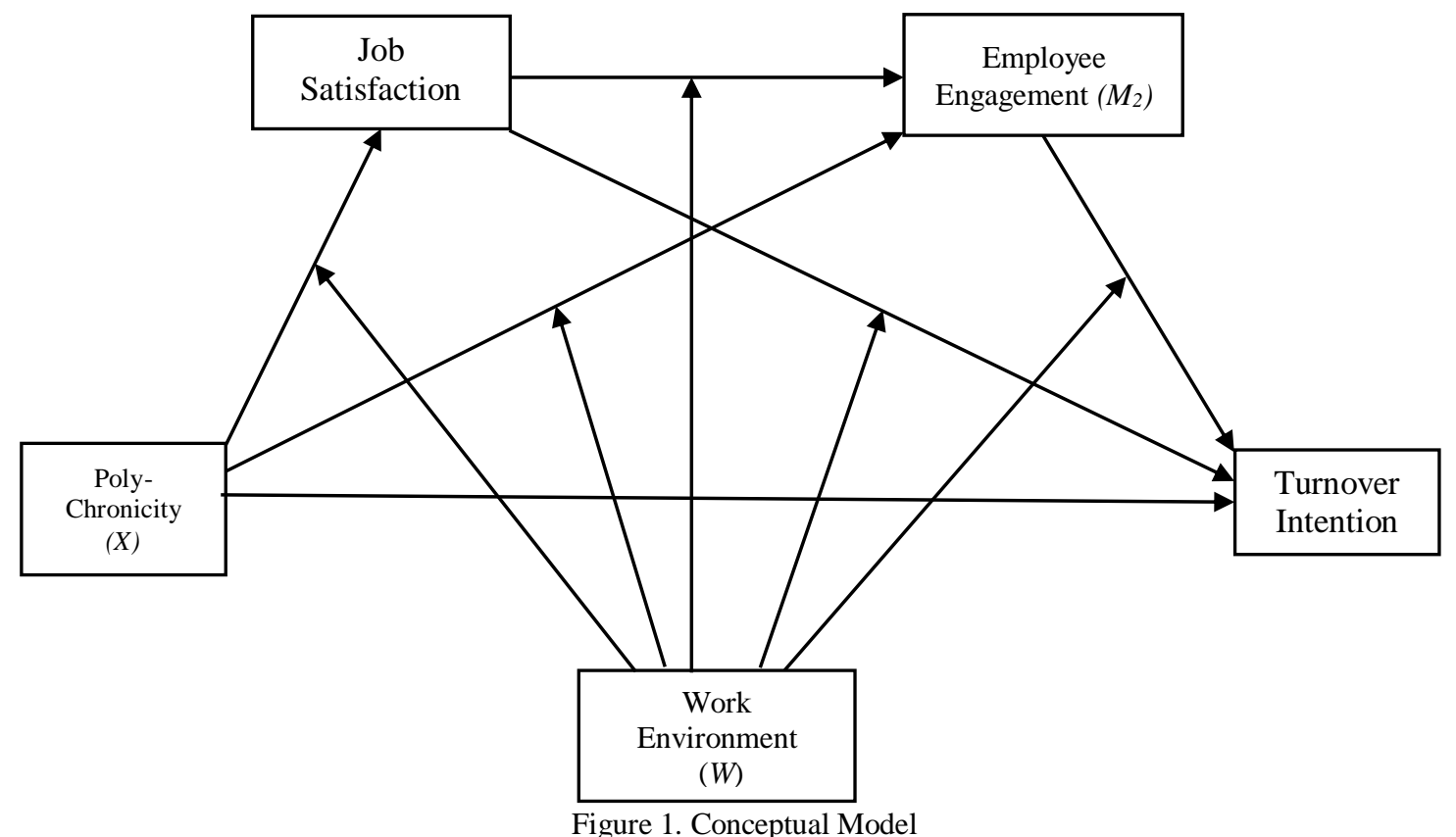

\section{Research Method}

Testing the conditional process model uses path analysis based on OLS (Ordinary Least Square) regression. The bootstrap method uses statistical tools SPSS version 23 and PROCESS version 3.4 by Andrew F. Hayes, the 92 models of the object of this study. This test is performed to measure the direct effect and indirect effect and the total effect of the independent variable on the dependent variable. The research conceptual model that this research includes is the conditional process model or the 92 models developed by Hayes. Conditional process analysis is a combination and focuses on estimating and interpreting the conditional properties (moderation component) of the indirect and/or direct (mediation) effects of $\mathrm{X}$ on $\mathrm{Y}$ in the causal system (Hayes, 2018). The analytical model in moderating and mediating variables combined into an integrated model (conditional process model) by designing a model supported by previous research data is a new model for analyzing research to reduce employee turnover intention. The conceptual gap poured into the statistical gap is a research gap from the conditional process model research by analyzing the factors that affect employee turnover intention. Conditional process analysis describes and understands conditional properties through mechanisms that transmit influence between variables (Hayes, 2013).

Considering the time, costs, and permits, the population of this study are the hotel industry employees who had previously agreed at the Focus Group Discussion meeting with the Hotel Human Resources Managers Association (HHRMA), which were 12 hotels with a total of 717 employees. The sample was determined using the Slovin formula with an alpha level of 5\% (Sevilla, 2007) so that the research sample was 257 employees. The research data were obtained through questioner regarding job satisfaction, employee engagement, work environment, and turnover intention. The Likert scale is used in 7 categories because it is effortless and popular to express the degree (agreement) from strongly disagree ( score $=1)$ to strongly agree $($ score $=7$ ) on several questions/statements (Dunn-Rankin et al., 2004).

\section{Result and Discussion}

Based on the results of data processing in Figure 2, it can be seen that the effect of polychronicity (X) on turnover intention (Y) is significant. The effect of $\mathrm{X}$ to job satisfaction (M1) is significant and the effect of M1 to $\mathrm{Y}$ is significant. The effect of $\mathrm{X}$ to $\mathrm{Y}$ after entering M1 becomes insignificant (because between the BootLLCI to BootULCI values, there are zero numbers. It is concluded that the effect of mediation is not significant at the $5 \%$ significance level). A conclusion that M1 is full mediation, meaning 
that job satisfaction mediates the polychronic effect on industrial employees' turnover intention by the work environment. Furthermore, Figure 2 concluded that the effect of $\mathrm{X}$ polychronic $(\mathrm{X})$ on turnover intention (Y) is significant. The effect of $\mathrm{X}$ to employee engagement (M2) is significant and the effect of $\mathrm{M} 2$ to $\mathrm{Y}$ is significant. The effect of $\mathrm{X}$ to $\mathrm{Y}$ after entering $\mathrm{M} 2$ becomes significant (because between the BootLLCI to BootULCI values, there are zeros in the W 50th and 84th percentile values. It is concluded that the mediation effect is significant at the 5\% significance level). The conclusion that M2 is partial mediation, meaning that employee engagement does not mediate the effect of polychronicity on turnover intention of hotel industry employees, which is moderated by the work environment.

Meanwhile, Figure 3 shows that the effect of polychronicity $(\mathrm{X})$ on turnover intention $(\mathrm{Y})$ is significant. The effect of $\mathrm{X}$ to job satisfaction (M1) is significant, the effect of M1 to $\mathrm{Y}$ is significant, the effect of $\mathrm{X}$ to $\mathrm{M} 2$ is significant and the effect of $\mathrm{M} 2$ to $\mathrm{Y}$ is significant. The effect of $\mathrm{X}$ to $\mathrm{Y}$ after inserting M1 and M2 becomes insignificant (because between BootLLCI and BootULCI values contain zero, it is concluded that the mediation effect is not significant at the 5\% significance level). Conclusion M1 and M2 are full mediation, meaning that job satisfaction and engagement mediate the effect of polychronicity on employee turnover intention in the hotel industry, which is moderated by the work environment.

The results of the conditional indirect effect on the effect of polychronicity on turnover intention of hotel industry employees as seen in Figure 4, M1 and M2 are full mediation, meaning that job satisfaction and engagement mediate the effect of polychronicity on the turnover intention of the hotel industry employees which is moderated by the work environment. To get the results of the analysis of the influence of polychronic and turnover intention, it must be parallel through job satisfaction and employee engagement moderated by a conducive work environment. Comprehensively, this study's finding that the effect of polychronicity on turnover intention must go through full mediation of job satisfaction and employee engagement variables moderated by the work environment so that it is called a conditional process.

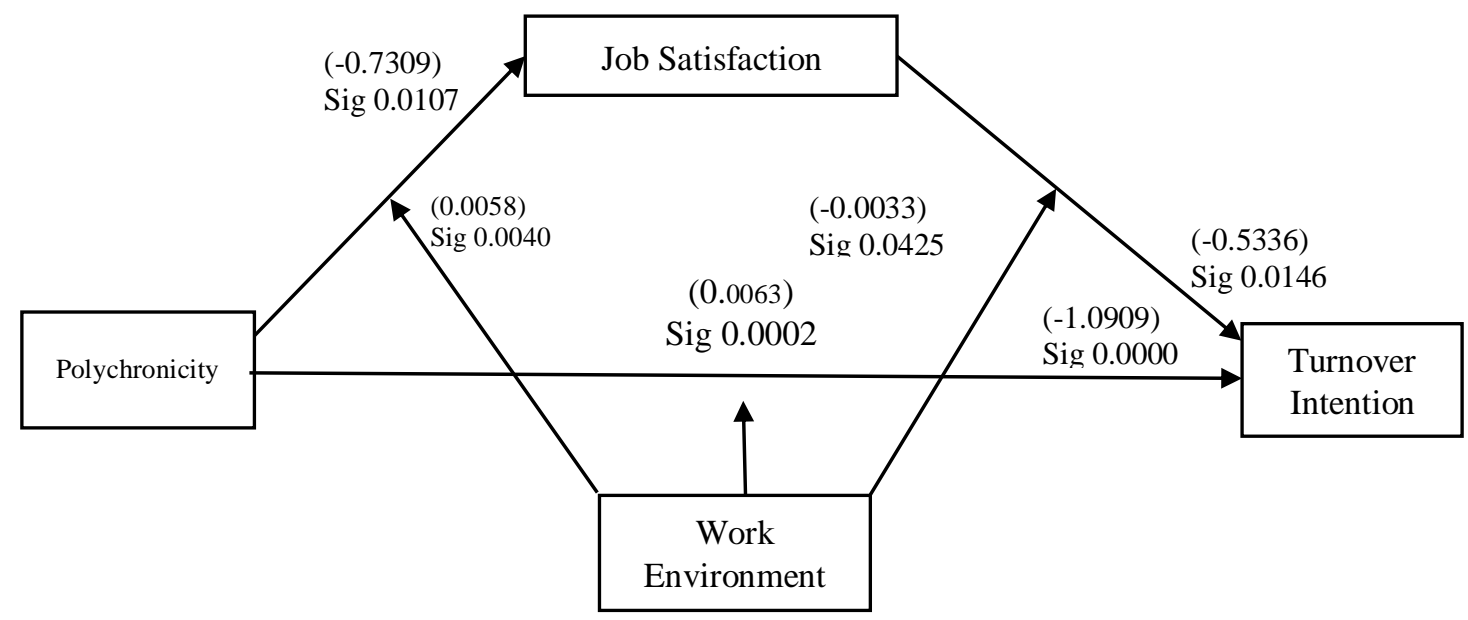

Figure 2. The Effect of Polychronicity on Turnover Intention through Job Satisfaction Moderated by the Work Environment

The average support for the hotel industry's work environment in Indonesia is high. Based on the test results, it is proven that a conducive work environment can interact so that it effectively moderates the relationship between polychronic and job satisfaction. If polychronic increases, job satisfaction will increase if moderated by the work environment. The work environment in the hospitality industry demands polychronic behavior, which requires employees to deal with two or more activities in the same period of time (Slocombe \& Bluedorn, 1999). To remain satisfied under such a work environment, employees in service organizations such as hotels must have sufficient characteristics that best suit the hospitality industry (Jang \& George, 2012). This is supported by the Person-Environment theory (P-E theory), which refers to the compatibility between individuals and their work environment (Ehrhart \& Makransky, 2007). The main idea of the P-E theory is that individual characteristics match the attributes of the work environment in predicting the perceptions that individuals have about how well they fit into their work environment, which affects job outcomes such as job satisfaction (Verquer et al., 2003).

Given that the hotel industry stands out as a work environment where a shift in work-handling behavior is often required, polychronic plays an important role in enhancing positive employment outcomes; for example, highly polychronic individuals may interact with several customers once. Such people's preference for time use fits well with a hotel work environment involving multiple tasks and 
frequent shifting behavior in the workstream (Jang \& George, 2012).

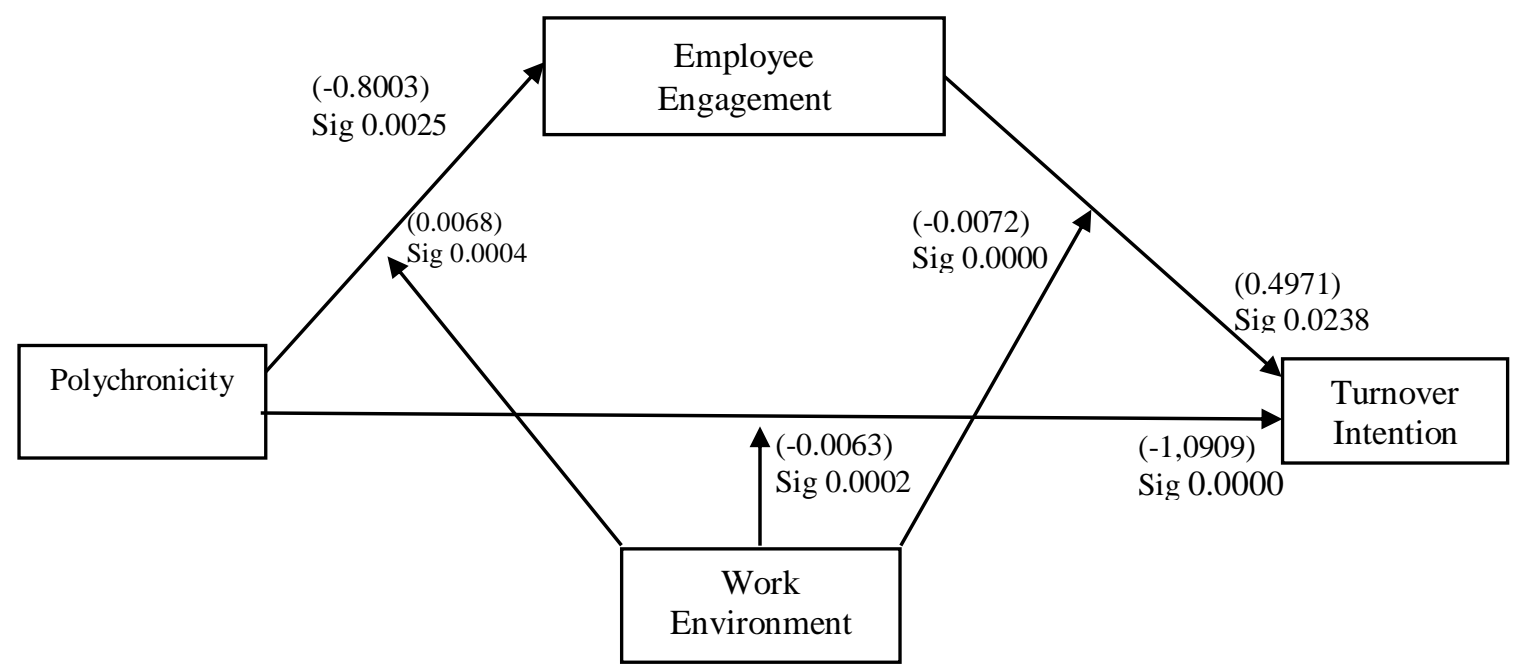

Figure 3. The Effect of Polychronicity on Turnover Intention through Employee Engagement Moderated by the Work Environment

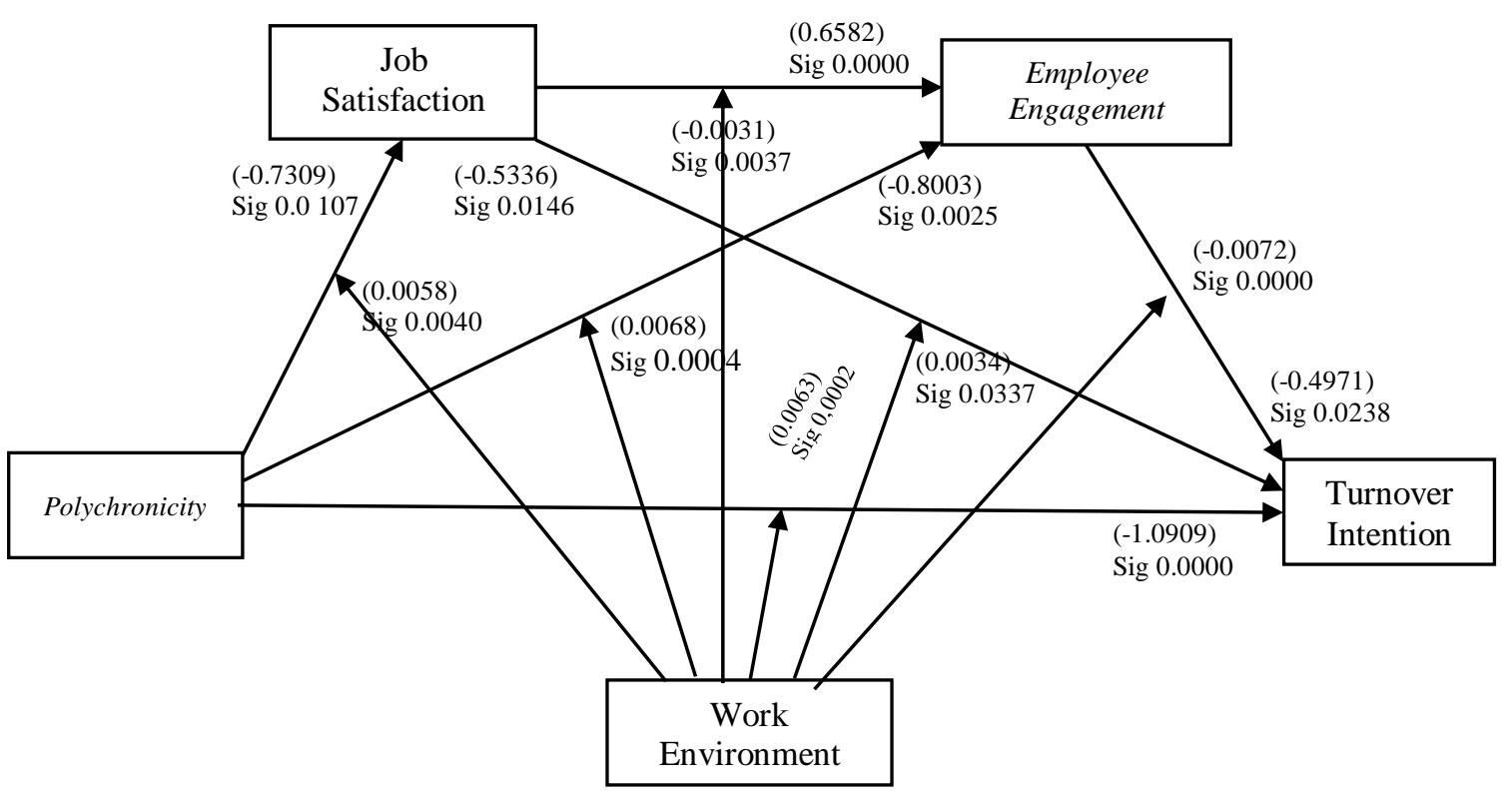

Figure 4. The Effect of Polychronicity on Turnover Intention through Job Satisfaction and Employee Engagement Moderated by Work environment

The hotel industry is a place where time management is critical, and a shift in behavior between jobs is often required within a certain period of time (Jang \& George, 2012). Various patterns of time utilization have received attention about effective workplace behavior (Bluedorn et al., 1992). When competitive pressures increase in a rapidly changing environment, employees are required to engage in a variety of additional tasks, activities, and roles that they must simultaneously handle (Lynne Persing, 1999). In the hospitality industry, it is understood that employees are required to work in a fast-paced environment (Karatepe \& Uludag, 2007). Given the special features of the service industry, hotel employees have a high level of personal contact with hotel guests. They need to be able to handle some work while busy. Often, their attention needs to be distributed evenly across multiple jobs to respond to hotel guests' needs promptly. During work, hotel employees are exposed to many unknown and unexpected situations. In the industrial era 4.0 all hotel employees are required to be connected in networks, technology and information, this is expected to facilitate or smooth their work so that they can behave polychronic, with digitalization, hotel 
employees can more easily interact with other hotel employees and hotel guests. . And the habits of employees in applying technology and information to their work environment, namely in the hotel industry are the implementation of the 5.0 era.

The average support for the hotel industry's work environment in Indonesia is high. Based on the test results, it is proven that a conducive work environment can interact so that it effectively moderates the effect of job satisfaction on employee engagement. It can be concluded that high job satisfaction and a reinforced conducive work environment can increase employee engagement in the hotel industry. The work environment has high interaction in increasing job satisfaction on employee engagement in the hotel industry. Employees who feel engaged can find full meaning, have satisfaction at work, receive positive coworker support, and work in their work environment effectively and efficiently. The work environment can influence job satisfaction on employee engagement because the work environment is an important element in an organization (industry) that strongly influences individual behavior. A conducive work environment is one of the factors that can foster employee engagement. The comfort of working environment conditions triggers the creation of employee engagement. Employee engagement has a concept in employee job effectiveness, as the need to develop and provide innovation with a work environment that facilitates each other's work to lead to effectiveness and job satisfaction. Job satisfaction is a pleasant psychological state that employees in a work environment feel because their needs are met adequately. To create a positive value situation in the hotel industry work environment is the obligation of each line of leadership of the company concerned. Employees engaged with the workplace will have high job satisfaction and positive attitudes towards the work environment.

The higher employees' job satisfaction in their work environment, it is expected that their level of participation in handling work is also high. The high level of employee participation with various events in the company will cause employees to be more engaged with their work and work environment. Job satisfaction is a person's response to the work environment they face. Hotel industry employees in Indonesia consider work to be a challenge in itself that must be resolved. The work environment supports employees to be able to work optimally. Employees who are supported by a conducive work environment will feel comfortable and supported to work well. Employees like a comfortable physical environment, such as temperature, lighting, sound, and other physical environmental factors that should not be extreme, such as too hot or poor lighting and a conducive non-physical environment. In general, employees like jobs close to home, clean and modern facilities, adequate tools, and equipment.

When job satisfaction increases, employees will feel happy to continue working there, reinforced by a conducive work environment that will increase high loyalty to reduce employee turnover. One of the factors that can affect job satisfaction is a conducive work environment, which can strengthen or weaken the relationship with employee engagement. The results showed that the interaction of the work environment could reduce the effect of job satisfaction on employee engagement. This can be caused by the age factor of employees who are on average under 35ars of age so that the possibility of them looking for a more secure job with a higher salary can still occur.

The average support for the hotel industry's work environment in Indonesia is high. Based on the test results, it is proven that a conducive work environment can interact. It effectively moderates the effect of engagement on the turnover intention of hotel industry employees. The nature of the hospitality industry requires employees in prime service jobs to engage in several challenging prime service jobs. Hotel employees are expected to provide quality services to hotel guests and handle hotel guest requests and problems successfully (Karatepe \& Uludag, 2007). In these circumstances, the hotel manager needs to acquire and retain a group of hotel employees who can display a meticulous effort to complete various tasks. Polychronic individuals can play an important role in this process.

A conducive work environment can reduce employee turnover intention as a moderating variable. If employees work in good working conditions and are supported by facilities, facilities, and infrastructure to support their work, they will feel bound and comfortable at work. Employees will be enthusiastic and provide good service to guests and colleagues. A conducive work environment will provide high engagement to establish a conducive working mechanism. Employee turnover intention can be suppressed by a supportive work environment where employees will feel excited about the work atmosphere with both physical and non-physical environments. The emergence of morale, dedication, and absorption in employees supported by a conducive work environment can increase employee engagement to reduce the turnover intention rate of employees in the hotel industry. A conducive work environment is a prerequisite to reduce employee turnover intention. Hence, the hotel, in this case, the manager, needs to pay attention to and continue to improve the conducive work environment to increase job satisfaction, increase employee engagement and reduce turnover rates. 


\section{Conclusions, suggestions and limitations}

This study reveals that the work environment is proven to be effective in moderating the effect of polychronicity on employee job satisfaction, meaning that polychronic can increase employee job satisfaction in the hotel industry, which is moderated by a conducive work environment; the work environment is proven to be effective in moderating the effect of polychronicity on employee engagement, meaning that polychronic can increase employee engagement in the hotel industry which is moderated by a conducive work environment. The work environment is also effective in moderating job satisfaction on employee engagement, meaning that employee job satisfaction can increase employee engagement in the hotel industry, which is moderated by a conducive work environment. The higher the level of polychronic effectiveness, employee job satisfaction, and the level of conductivity of the work environment will increase employee engagement in the hotel industry.

The work environment in moderating the effect of polychromic on employee turnover intention show effectiveness, meaning that polychronic can reduce the turnover intention of hotel industry employees, which is moderated by a conducive work environment. The work environment is proven to be effective in moderating employee job satisfaction on employee turnover intention, meaning that employee job satisfaction can reduce the turnover intention rate of hotel industry employees, which is moderated by a conducive work environment. The work environment is proven to be effective in moderating employee engagement on employee turnover intention, meaning that employee engagement behavior can reduce the turnover intention rate of hotel industry employees, which is moderated by a conducive work environment. The higher the level of polychronic effectiveness, the level of job satisfaction, the level of employee engagement, and the level of conduciveness of the work environment, the lower the turnover intention rate for hotel industry employees.The research findings are expected to assist hotel managers in selecting candidates that are most suitable for their organization (hotel industry). It will also assist employees in determining which career path best fits their personality traits. The confirmation of this relationship can serve as useful pre-hiring information for hotel managers. In addition to regular personality tests, human resources departments can use time usage preferences as a reference to test whether they feel comfortable working in a hospitality industry environment that requires multitasking skills. Before applying for a job, it is very important for applicants to know their time allocation preferences so that they can pursue the position that best suits their personality.

Business potential in the hotel industry is always increasing, supported by the number of Indonesian residents and tourism potential, which is quite attractive, and many choices can attract tourists to visit. The hotel industry as a tourism sector is one of the sectors that must be ready to face the industrial era 4.0 because conditions in the hotel industry are always experiencing rapid development. Employees in the hospitality industry must interact with the concept of digitization by utilizing digital technology in serving hotel guests. The readiness of hotel employees in the 4.0 industrial revolution requires competent skills and abilities both from the operational field to the top management level. All employees in the hospitality industry must be able to enhance technology-based professionalism. Every hotel employee is required to understand the duties and functions according to their department.

Hotel employees must also be ready to enter the era of society 5.0 in enhancing human capabilities to open up every opportunity for humanity so that humans can be transformed to carry out their work in a meaningful way where the work environment becomes one of the elements. The era of society 5.0 is a concept that is human-centered and technology-based. Hotel employees must interact with internal and external parties based on technology that can support multitasking behavior to increase job satisfaction and employee engagement in the hotel industry supported by a conducive work environment.

The hotel indufiguis one of the industries that have a high turnover rate in Indonesia. It is hoped that further researchers will be able to continue research in a wider area. Hospitality industry employees who are used as research samples consist of employees from several hotels due to limited licensing from the industry. It will be more comprehensive and representative in the future if the sample is expanded based on the hotel classification. For further researchers, it is hoped that they can take respondents who are more specific in their positions, for example, at the low management, middle management, or top management levels, so that it will be known which level has a higher turnover rate so that it can be analyzed to find a solution. The hotel has several departments, including the food and beverage department, front office department, housekeeping department, accounting department, Human Resources Development (HRD) department, engineering department, and marketing department, which can be researched next, which department has a higher turnover rate to analyze the solution.. 


\section{References}

AbuAlRub, R., El-Jardali, F., Jamal, D., \& Abu Al-Rub, N. (2016). Exploring the relationship between work environment, job satisfaction, and intent to stay of Jordanian nurses in underserved areas. Applied Nursing Research, 31, 19-23. https://doi.org/10.1016/j.apnr.2015.11.014

Afzalur Rahim, M., Civelek, I., \& Liang, F. H. (2015). A model of department chairs' social intelligence and faculty members' turnover intention. Intelligence, 53, 65-71. https://doi.org/10.1016/j.intell.2015.09.001

Aksu, A. (2008). Employee Turnover: Calculation of Turnover Rates and Costs. In Handbook of Hospitality Human Resources Management (Second, pp. 195-222). Elsevier Ltd. https://doi.org/10.1016/B9780-08-045081-0.50013-6

Alniaçik, E., Alniaçik, Ü., Erat, S., \& Akçin, K. (2013). Does Person-organization Fit Moderate the Effects of Affective Commitment and Job Satisfaction on Turnover Intentions? Procedia - Social and Behavioral Sciences, 99, 274-281. https://doi.org/10.1016/j.sbspro.2013.10.495

Amundsen, S., \& Martinsen, O. L. (2014). Self-other agreement in empowering leadership: Relationships with leader effectiveness and subordinates' job satisfaction and turnover intention. Leadership Quarterly, 25(4), 784-800. https://doi.org/10.1016/j.leaqua.2014.04.007

Andriani, R. (2014). Pengaruh Budaya Organisasi Dan Kompetensi Terhadap Kepuasan Kerja Karyawan Pada Bank Tabungan Negara Di Bandung. Jurnal Ecodemica: Jurnal Ekonomi, Manajemen, Dan Bisnis, 2(2), 247-257.

Andriani, R., Disman, Ahman, E., Yuniarsih, T., \& Santoso, B. (2019). Polychronic Behaviors: The Role Of Job Residency and Education Level. International Journal of Entrepreneurship, 23(3), 1-5. https://www.abacademies.org/articles/Polychronic-behaviors-the-role-of-job-residency-andeducation-level-1939-4675-23-3-297.pdf

Andriani, R., \& Disman, D. (2020). Polychronicity in the Hotel Industry in Bandung City. In Advances in Business, Management and Entrepreneurship. Taylor \& Francis Group.

Arkhani, F. L. (2017). Hubungan Antara Persepsi Gaya Kepemimpinan Transformasional Dengan Employee Engagement Pada Karyawan Hotel X Solo.

Armstrong, M., \& Taylor, S. (2014). Human Resource Management Practice (Thirteen). Kogan Page.

Arndt, A., Arnold, T. J., \& Landry, T. D. (2006). The effects of polychronic-orientation upon retail employee satisfaction and turnover. Journal of Retailing, 82(4), 319-330. https://doi.org/10.1016/j.jretai.2006.08.005

Beardwell, J., \& Thompson, A. (2017). Human Resource Management (Eight). Pearson.

Bluedorn, A. C. (1998). An Interview With Anthropologist Edward T. Hall. Journal of Management Inquiry, 7(2), 109-115.

Bluedorn, A. C., Felker Kaufman, C., \& Lane, P. M. (1992). How many things do you like to do at once? An introduction to monochronic and polychronic time. Academy of Management Executive, 6(4), 1726. https://doi.org/10.5465/ame.1992.4274453

Bluedorn, A. C., \& Jaussi, K. S. (2007). Multi-Level Issues in Organizations and Time. Multil-Level Issues in Organizations and Time, 6, 187-223.

Bluedorn, A. C., Kalliath, T. J., Strube, M. J., \& Martin, G. D. (1999). Polychronicity and the Inventory of Polychronic Values (IPV):The development of an instrument to measure a fundamental dimension of organizational culture. Journal of Managerial Psychology, 14, 205-231. https://doi.org/10.1108/02683949910263747

Boev, C., Xue, Y., \& Ingersoll, G. L. (2015). Nursing job satisfaction, certification and healthcareassociated infections in critical care. Intensive and Critical Care Nursing, 31(5), 276-284. https://doi.org/10.1016/j.iccn.2015.04.001

Boss, J. (2018). Employee Turnover Is The Highest It's Been In 10 Years. Here's What To Do About It. Forbes Media LLC.

Brimhall, K. C., Lizano, E. L., \& Mor Barak, M. E. (2014). The mediating role of inclusion: A longitudinal study of the effects of leader-member exchange and diversity climate on job satisfaction and intention to leave among child welfare workers. Children and Youth Services Review, 40, 79-88. https://doi.org/10.1016/j.childyouth.2014.03.003

Budiyanti, H., Pintor, S., \& Patiro, S. (2018). Perceived Fairness , Emotions, and Intention of Fast Food Chain Restaurants Customers in Indonesia. 20(2), 229-253.

Chan, S. H. J., Mai, X., Kuok, O. M. K., \& Kong, S. H. (2016). The influence of satisfaction and promotability on the relation between career adaptability and turnover intentions. Journal of Vocational Behavior, 92, 167-175. https://doi.org/10.1016/j.jvb.2015.12.003

Collins, M. D. (2010). The effect of psychological contract fulfillment on manager turnover intentions and 
its role as a mediator in a casual, limited-service restaurant environment. International Journal of Hospitality Management, 29(4), 736-742. https://doi.org/10.1016/j.ijhm.2010.03.005

Coomber, B., \& Louise Barriball, K. (2007). Impact of job satisfaction components on intent to leave and turnover for hospital-based nurses: A review of the research literature. International Journal of Nursing Studies, 44(2), 297-314. https://doi.org/10.1016/j.ijnurstu.2006.02.004

Danish, R. Q., Ramzan, S., \& Ahmad, F. (2013). Effect of Perceived Organizational Support and Work Environment on Organizational Commitment; Mediating Role of Self-Monitoring. Advances in Economics and Business, 1(4), 312-317. https://doi.org/10.13189/AEB.2013.010402

De Cuyper, N., Mauno, S., Kinnunen, U., \& Mäkikangas, A. (2011). The role of job resources in the relation between perceived employability and turnover intention: A prospective two-sample study. Journal of Vocational Behavior, 78(2), 253-263. https://doi.org/10.1016/j.jvb.2010.09.008

De Simone, S., Planta, A., \& Cicotto, G. (2018). The role of job satisfaction, work engagement, self-efficacy and agentic capacities on nurses' turnover intention and patient satisfaction. Applied Nursing Research, 39, 130-140. https://doi.org/10.1016/j.apnr.2017.11.004

Dick, R. Van, Christ, O., Stellmacher, J., Wagner, U., Ahlswede, O., Grubba, C., Hauptmeier, M., Moltzen, K., \& Tissington, P. A. (2004). Should I Stay or Should I Go Explaining Turnover Intentions with Organizational Identification and Job Satisfaction.pdf. British Journal of Management, 15, 351-360. https://doi.org/10.1081/JFP-120016626

Dilig-Ruiz, A., MacDonald, I., Demery Varin, M., Vandyk, A., Graham, I. D., \& Squires, J. E. (2018). Job satisfaction among critical care nurses: A systematic review. International Journal of Nursing Studies, 88, 123-134. https://doi.org/10.1016/j.ijnurstu.2018.08.014

Dunn-Rankin, P., Knezek, G., Wallace, S., \& Zhang, S. (2004). Scaling Methods. Journal of Alternative Investments, 10(2), 76-84.

Dwiyanti, R., Hamzah, H. B., \& Abas, N. B. (2019). Job satisfaction, psychological contracts, and turnover intention: Role of social support as a mediator. International Journal of Research in Business and Social Science (2147-4478), 8(6), 96-104. https://doi.org/10.20525/ijrbs.v8i6.319

Ehrhart, K. H., \& Makransky, G. (2007). Testing vocational interests and personality as predictors of person-vocation and person-job fit. Journal of Career Assessment, 15(2), 206-226. https://doi.org/10.1177/1069072706298105

Elçi, M., Karabay, M. E., Alpkan, L., \& Şener, İ. (2014). The Mediating Role of Mobbing on the Relationship between Organizational Silence and Turnover Intention. Procedia - Social and Behavioral Sciences, 150, 1298-1309. https://doi.org/10.1016/j.sbspro.2015.01.110

Farooqui, M. S., \& Nagendra, A. (2014). The Impact of Person Organization Fit on Job Satisfaction and Performance of the Employees. Procedia Economics and Finance, 11(14), 122-129. https://doi.org/10.1016/s2212-5671(14)00182-8

Goonetilleke, R. S., \& Luximon, Y. (2010). The relationship between monochronicity, polychronicity and individual characteristics. Behaviour and Information Technology, 29(2), 187-198. https://doi.org/10.1080/01449290903222697

Gözükara, İ., \& Çolakoğlu, N. (2016). The Mediating Effect of Work Family Conflict on the Relationship between Job Autonomy and Job Satisfaction. Procedia - Social and Behavioral Sciences, 229, 253266. https://doi.org/10.1016/j.sbspro.2016.07.136

Grobelna, A. (2019). Effects of individual and job characteristics on hotel contact employees' work engagement and their performance outcomes: A case study from Poland. International Journal of Contemporary Hospitality Management, 31(1), 349-369. https://doi.org/10.1108/IJCHM-08-20170501

Grobelna, A., Sidorkiewicz, M., \& Tokarz-Kocik, A. (2016). Job satisfaction among hotel employees: Analyzing selected antecedents and job outcomes. A case study from Poland. Argumenta Oeconomica, 37(2), 281-310. https://doi.org/10.15611/aoe.2016.2.11

Hayes, A. F. (2013). Introduction to Mediation, Moderation, and Conditional Process Analysis. The Guilford Press. https://doi.org/10.4324/9781351239585-39

Hayes, A. F. (2018). Introduction to Mediation, Moderation, and Conditional Process Analysis (Second). The Guilford Press.

Hecht, T. D., \& Allen, N. J. (2005). Exploring links between polychronicity and well-being from the perspective of person-job fit: Does it matter if you prefer to do only one thing at a time? Organizational Behavior and Human Decision Processes, 98(2), 155-178. https://doi.org/10.1016/j.obhdp.2005.07.004

Huang, M., Li, P., Meschke, F., \& Guthrie, J. P. (2015). Family firms, employee satisfaction, and corporate performance. Journal of Corporate Finance, 34, 108-127. 
https://doi.org/10.1016/j.jcorpfin.2015.08.002

Ivancevich, J. M., Konopaske, R., \& Matteson, M. T. (2014). Organizational Behavior and Management (Tenth). McGraw-Hill.

Jang, J., \& George, R. T. (2012). Understanding the influence of polychronicity on job satisfaction and turnover intention: A study of non-supervisory hotel employees. International Journal of Hospitality Management, 31(2), 588-595. https://doi.org/10.1016/j.ijhm.2011.08.004

Kabak, K. E., Şen, A., Göçer, K., Küçüksöylemez, S., \& Tuncer, G. (2014). Strategies for Employee Job Satisfaction: A Case of Service Sector. Procedia - Social and Behavioral Sciences, 150, 1167-1176. https://doi.org/10.1016/j.sbspro.2014.09.132

Kantrowitz, T. M., Grelle, D. M., Beaty, J. C., \& Wolf, M. B. (2012). Time Is Money: Polychronicity as a Predictor of Performance Across Job Levels. Human Performance, 25(2), 114-137. https://doi.org/10.1080/08959285.2012.658926

Karatepe, O. M., \& Uludag, O. (2007). Conflict, exhaustion, and motivation: A study of frontline employees in Northern Cyprus hotels. International Journal of Hospitality Management, 26(3), 645-665. https://doi.org/10.1016/j.ijhm.2006.05.006

Kayaalp, A. (2014). The octopus approach in time management: Polychronicity and creativity. Military Psychology, 26(2), 67-76. https://doi.org/10.1037/mil0000032

Khuong, M. N., \& Vu, P. Le. (2014). Measuring the Effects of Drivers Organizational Commitment through the Mediation of Job Satisfaction A Study in Ho Chi Minh City, Vietnam. International Journal of Current Research and Academic Review, 2(2), 1-16.

König, C. J., \& Waller, M. J. (2010). Time for reflection: A critical examination of polychronicity. Human Performance, 23(2), 173-190. https://doi.org/10.1080/08959281003621703

Lu, L., Lu, A. C. C., Gursoy, D., \& Neale, N. R. (2016). Work engagement, job satisfaction, and turnover intentions: A comparison between supervisors and line-level employees. International Journal of Contemporary Hospitality Management, 28(4), 737-761. https://doi.org/10.1108/IJCHM-07-20140360

Lynne Persing, D. (1999). Managing in polychronic times. Journal of Managerial Psychology, 14(5), 358373. https://doi.org/10.1108/02683949910277111

Mano-Negrin, R., \& Tzafrir, S. S. (2004). Job search modes and turnover. Career Development International, 9(5), 442-458. https://doi.org/10.1108/13620430410550727

Monica, N. M. T. J., \& Putra, M. S. (2017). Pengaruh Stres Kerja, Komitmen Organisasional, Dan Kepuasan Kerja Terhadap Turnover Intention. E-Jurnal Manajemen Unud, 6(3), 1644-1673.

Moorhead, G., \& Griffin, R. W. (2013). Organizational behavior: managing people and organizations (Ninth). Cengage Learning Asia Pte Ltd.

Mount, D. J., \& Bartlett, A. L. "Bart." (2002). Development of a Job Satisfaction Factor Model for the Lodging Industry. Journal of Human Resources in Hospitality \& Tourism, 1(1), 17-39. https://doi.org/10.1300/J171v01n01_02

Nadiri, H., \& Tanova, C. (2010). An investigation of the role of justice in turnover intentions, job satisfaction, and organizational citizenship behavior in hospitality industry. International Journal of Hospitality Management, 29(1), 33-41. https://doi.org/10.1016/j.ijhm.2009.05.001

Noor, D., \& Rokhimakhumullah, F. (2017). The Effect Of Performance Measurement System And Remuneration To Employee Performance With Organizational Culture As A Moderating Variable. Journal of Innovation in Business and Economics, 01(01), 93-100.

Norris, J. (2015). Making Polychronic Objects. Research Through Design, March, 25-27. https://doi.org/10.6084/m9.figshare.1327941.Making

Onken, M. H. (1999). Temporal elements of organizational culture and impact on firm performance. Journal of Managerial Psychology, 14(3), 231-244. https://doi.org/10.1108/02683949910263756

Ozkan, A. H., Elci, M., Karabay, M. E., Kitapci, H., \& Garip, C. (2020). Antecedents of turnover intention: A meta-analysis study in the United States. E a M: Ekonomie a Management, 23(1), 93-110. https://doi.org/10.15240/tul/001/2020-1-007

Page, M. (2015). Employee Intentions Report Indonesia.

Palmer, D. (2006). Pol Ychronic Leader: What Would Leadership Research Look Like If We Considered Pol Ychronicity? Journal of Business and Leadership, 2(1), 99-107.

Palmer, D. K., \& Schoorman, F. D. (1999). Unpackaging the multiple aspects of time in polychronicity. Journal of Managerial Psychology, 14, 323-345. https://doi.org/10.1108/02683949910263918

Plocher, T., Goonetilleke, R. S., Yan, Z., \& Liang, S.-F. M. (2002). Time Orientation Across Cultures. Proceedings of the 4th, 23-31.

Poposki, E. M., \& Oswald, F. L. (2009). Development of a New Measure of Polychronicity. 182-202. 
Poposki, E. M., Oswald, F. L., \& Brou, R. J. (2009). Development of a New Measure of Polychronicity.

Qureshi, M. I., Iftikhar, M., Abbas, S. G., Hassan, U., Khan, K., \& Zaman, K. (2013). Relationship between job stress, workload, environment and employees turnover intentions: What we know, what should we know. World Applied Sciences Journal, 23(6), 764-770. https://doi.org/10.5829/idosi.wasj.2013.23.06.313

Rahayu, N. M. N., \& Riana, I. G. (2017). Pengaruh Kompensasi Terhadap Kepuasan Kerja Dan Keinginan Keluar Pada Hotel Amaris Legian. E-Jurnal Manajemen Unud, 6(11), 5804-5833.

Reynolds, N. (2008). Time Orientation, Task Characteristics, and Customer Performance. 1-7.

Riani, N. L. T., \& Putra, M. S. (2017). Pengaruh Stres Kerja, Beban Kerja Dan Lingkungan Kerja Non Fisik Terhadap Turnover Intention Karyawan. E-Jurnal Manajemen Unud, 6(11), 5970-5998.

Robbins, S. P., \& Judge, T. A. (2018). Essentials of Organizational Behavior (Fourteenth).

Satwari, T., Musadieq, M. Al, Afrianty, T. W., Administrasi, F. I., \& Brawijaya, U. (2016). Pengaruh Komitmen Organisasional Terhadap Turnover ( Survei pada Karyawan Hotel Swiss-Belinn Malang ). $40(2)$.

Schaufeli, W., Salanova, M., González-romá, V., \& Bakker, A. (2002). The Measurement of Engagement and Burnout: A Two Sample Confirmatory Factor Analytic Approach. Journal of Happiness Studies, 3(1), 71-92. https://doi.org/10.1023/A:1015630930326

Schiemann, W. A. (2014). From talent management to talent optimization. Journal of World Business, 49(2), 281-288. https://doi.org/10.1016/j.jwb.2013.11.012

Sevilla, C. G. (2007). Research Methods. Rex Printing Company. Rex Printing Compan.

Shahpouri, S., Namdari, K., \& Abedi, A. (2016). Mediating role of work engagement in the relationship between job resources and personal resources with turnover intention among female nurses. Applied Nursing Research, 30, 216-221. https://doi.org/10.1016/j.apnr.2015.10.008

Shuck, B., \& Reio, T. G. (2014). Employee Engagement and Well-Being: A Moderation Model and Implications for Practice. Journal of Leadership \& Organizational Studies, 21(1), 43-58. https://doi.org/10.1177/1548051813494240

Shukla, S., \& Sinha, A. (2013). Employee Turnover in banking sector: Empirical evidence. IOSR Journal Of Humanities And Social Science, 11(5), 57-61.

Slocombe, T. E., \& Bluedorn, A. C. (1999). Organizational behavior implications of the congruence between preferred polychronicity and experienced work-unit polychronicity. Journal of Organizational Behavior, 20(1), 75-99. https://doi.org/10.1002/(SICI)10991379(199901)20:1<75::AID-JOB872>3.0.CO;2-F

Tsai, P. C., Yen, Y., \& Huang, L. (2007). A study on motivating employees 'learning commitment in the post-downsizing era: Job satisfaction perspective. 42, 157-169. https://doi.org/10.1016/j.jwb.2007.02.002

Turkyilmaz, A., Akman, G., Ozkan, C., \& Pastuszak, Z. (2011). Empirical study of public sector employee loyalty and satisfaction. Industrial Management \& Data Systems, 111(5), 675-696. https://doi.org/10.1108/02635571111137250

Uhl-Bien, M., Schermerhorn, J. R., \& Osborn, R. N. (2014). Organizational Behavior (Thirteenth). Wiley.

Valentine, S., Godkin, L., Fleischman, G. M., \& Kidwell, R. (2011). Corporate Ethical Values, Group Creativity, Job Satisfaction and Turnover Intention: The Impact of Work Context on Work Response. Journal of Business Ethics, 98(3), 353-372. https://doi.org/10.1007/s10551-010-0554-6

Verquer, M. L., Beehr, T. A., \& Wagner, S. H. (2003). A meta-analysis of relations between personorganization fit and work attitudes. Journal of Vocational Behavior, 63(3), 473-489. https://doi.org/10.1016/S0001-8791(02)00036-2

Widyantara, I. B. putra. (2015). Pengaruh Kepuasan Kerja Dan Komitmen Organisasi Terhadap Intensitas Turnover Karyawan. E-Jurnal Manajemen Unud, 4(6), 1670-1683.

Widyasari, N. M., Dewi, I. G. A. M., \& Subudi, M. (2017). Pengaruh Ketidakamanan Kerja Dan Kompensasi Terhadap Kepuasan Kerja Dan Turnover Intention Karyawan Besakih Beach Hotel Denpasar. E-Jurnal Ekonomi Dan Bisnis Universitas Udayana, 5, 2103-2132.

Yeh, Y.-P. (2014). Exploring the Impacts of Employee Advocacy on Job Satisfaction and Organizational Commitment: Case of Taiwanese Airlines. Journal of Air Transport Management, 36, 94-100. https://doi.org/10.1016/j.jairtraman.2014.01.002

Yuda, I. B. D. P., \& Ardana, I. K. (2017). Pengaruh Kepuasan Kerja Dan Stres Kerja Terhadap Turnover Intention Pada Karyawan Hotel Holiday Inn Express. E-Jurnal Manajemen Unud, 6(10), 5319-5347.

Zagladi, A. N., Hadiwidjojo, D., Rahayu, M., \& Noermijati. (2015). The Role of Job Satisfaction and Power Distance in Determining the Influence of Organizational Justice Toward the Turnover Intention. Procedia - Social and Behavioral Sciences, 211, 42-48. https://doi.org/10.1016/j.sbspro.2015.11.007 
Polychronicity: Model and analysis of conditional process... (Andriani, Disman, Ahman, Santoso)

Zhang, W. (2015). The Influence Of Polychronic Time Use On Job Satisfaction, Work Engagement, And Turnover Intention: A Study Of Non-Supervisory Restaurant Employees. Kansas State University. 